\title{
Atorvastatin reduces lipopolysaccharide-induced expression of C-reactive protein in human lung epithelial cells
}

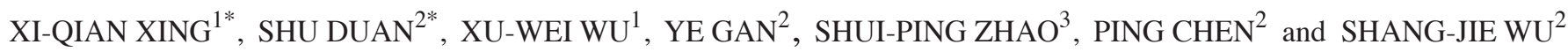 \\ ${ }^{1}$ First Department of Respiratory Medicine, Yan'An Hospital Affilliated to Kunming Medical College, Yunnan 650051; \\ Departments of ${ }^{2}$ Respiratory Medicine, and ${ }^{3}$ Cardiology, the Second Xiangya Hospital, \\ Central South University, Changsha, Hunan 410011, P.R. China
}

Received March 18, 2011; Accepted May 16, 2011

DOI: $10.3892 / \mathrm{mmr} .2011 .491$

\begin{abstract}
Accumulating evidence suggests that statins possess anti-inflammatory properties and may decrease C-reactive protein (CRP) levels in plasma. However, no studies have as yet addressed whether or not statins regulate the expression of CRP in human lung epithelial cells (A549). In this study, we determined whether atorvastatin modulates the lipopolysaccharide (LPS)-induced expression of CRP in A549 cells. A549 cells were incubated in Dulbecco's modified Eagle's medium containing LPS in the absence or presence of various concentrations of atorvastatin. After incubation, the medium was collected and the amount of CRP was measured by an enzyme-linked immunosorbent assay. The cells were harvested and CRP messenger ribonucleic acid (mRNA) was analyzed by reverse transcription polymerase chain reaction. Incubation with LPS induced a significant time- and dose-dependent increase in CRP mRNA expression and CRP production in A549 cells, whereas atorvastatin significantly decreased LPS-induced CRP mRNA expression and CRP production in a dose-dependent manner. The present study revealed that A549 cells are capable of LPS-induced CRP expression, and that atorvastatin down-regulates the LPS-induced expression of CRP in cultured A549 cells. Our results suggest that statins ameliorate lung inflammation by regulating CRP production in human lung epithelial cells.
\end{abstract}

\section{Introduction}

C-reactive protein (CRP) is an acute inflammatory marker that is mainly produced by hepatocytes (1). In response to tissue damage or inflammation, serum levels of CRP may increase 1000-fold from baseline concentrations of less than $2 \mathrm{mg} / \mathrm{l}$ (2).

Correspondence to: Dr Shang-Jie Wu, Department of Respiratory Medicine, the Second Xiangya Hospital, Central South University, No. 139 Middle Renmin Road, Changsha, Hunan 410011, P.R. China E-mail: shangjie_wu@yahoo.com

${ }^{*}$ Contributed equally

Key words: statins, C-reactive protein, human lung epithelial cell, lung inflammation, lipopolysaccharide
Although the elevated serum level of CRP is predominantly produced by hepatocytes (1), a number of studies have shown the extrahepatic synthesis of CRP (3-6). Certain studies have noted that human lung epithelial cells express CRP (7-10). Additionally, our research team has observed that the CRP concentration in the sputum of patients with chronic obstructive pulmonary disease (COPD) is significantly higher than that in the plasma of these patients (11). This evidence suggests that lung epithelial cells are a source of locally produced CRP.

On the other hand, inhibitors of 3-hydroxy-3-methylglutaryl coenzyme A reductase (or statins) are extensively used in medical practice, and large clinical trials have demonstrated that this class of lipid-lowering drugs greatly reduces cardiovascular-related morbidity and mortality in patients with and without coronary disease (12-14). Previous in vitro and in vivo findings indicate that in addition to their established cholesterol-lowering properties, statins exert a number of cholesterol-independent pleiotropic effects such as anti-inflammatory properties by affecting endothelium function, leukocyte adherence, platelet aggregation and depressing production of inflammatory factors (15-17). Statins have been shown to ameliorate local acute inflammatory reaction and decrease plasma levels of inflammatory markers, such as CRP $(18,19)$. Moreover, statins were previously shown to improve COPD survival $(20,21)$. However, the exact mechanism has yet to be elucidated.

Epithelial and endothelial cell permeability are increased during lung inflammation. Consequently, proteins such as CRP, released from lung epithelial cells, have the potential to enter the circulatory system (22). Thus, inhibiting CRP production in these cells may reduce serum CRP levels. However, whether or not atorvastatin affects CRP expression in human lung epithelial cells has yet to be examined. Due to the significance of CRP in inflammatory diseases, we examined the effects of atorvastatin on lipopolysaccharide (LPS)-induced expression of CRP in cultured human lung epithelial cells. .

\section{Materials and methods}

Materials. A human lung epithelial cell line (A549) was purchased from American Type Culture Collection (ATCC). Dulbecco's modified Eagle's medium (DMEM), trypsin, fetal bovine serum (FBS) and LPS were purchased from 
A

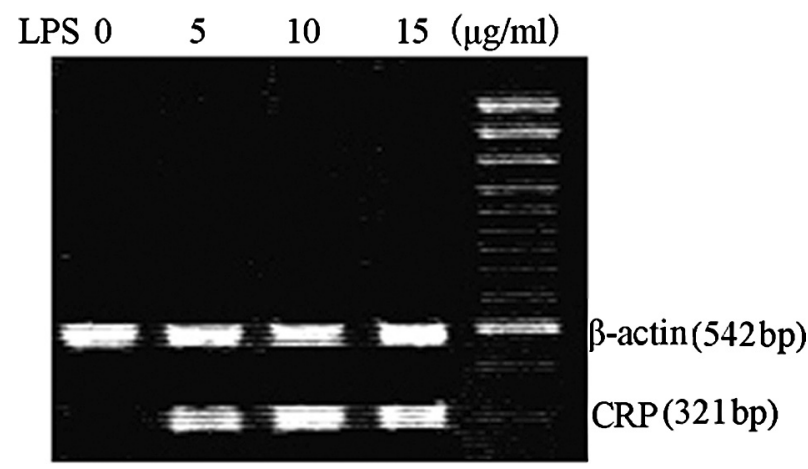

B

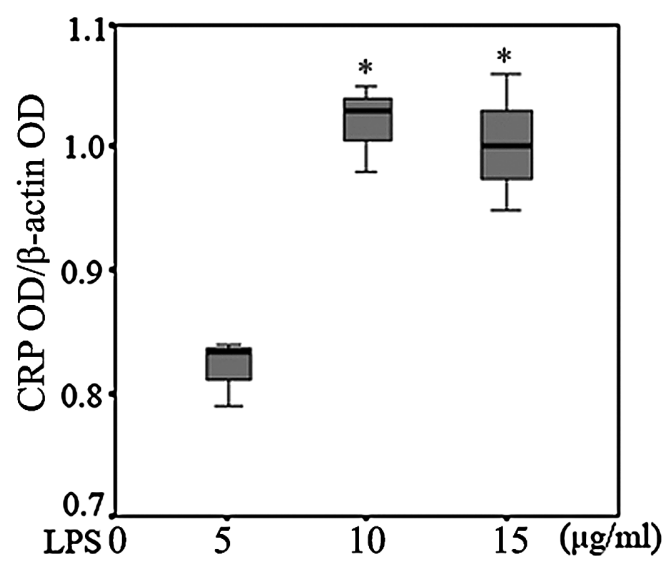

C

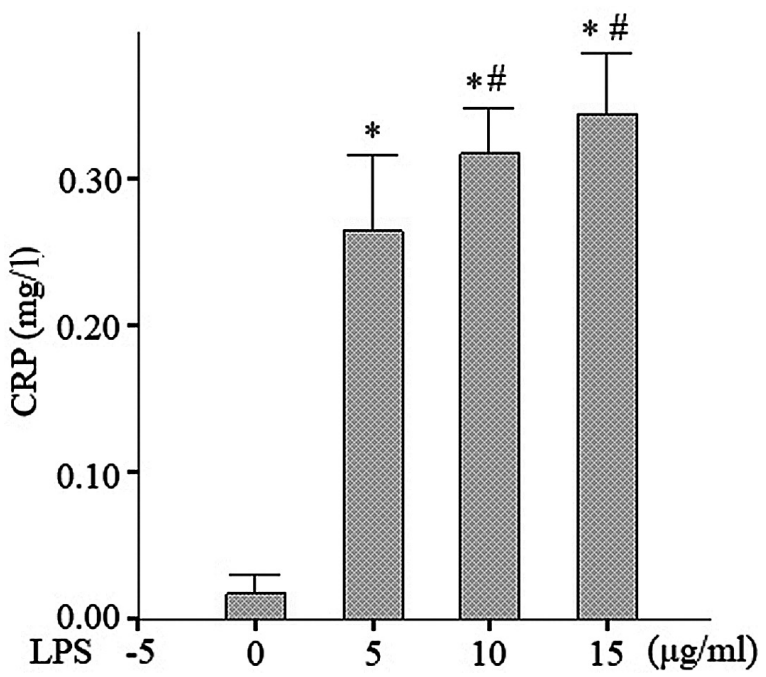

Figure 1. Dose-dependent effects of lipopolysaccharide (LPS) on C-reactive protein (CRP) mRNA expression and production. A549 cells were incubated with different concentrations of LPS for $24 \mathrm{~h}$. (A) A representative gel of CRP mRNA expression determined by RT-PCR. (B) Relative density of gel ( $\mathrm{p}=0.01 \mathrm{vs}$. LPS $5 \mu \mathrm{g} / \mathrm{ml}$ ). (C) CRP levels determined by ELISA at different LPS concentrations ( ${ }^{*} \mathrm{p}<0.001$ vs. non-LPS group; ${ }^{*} \mathrm{p}<0.05$ vs. $5 \mu \mathrm{g} / \mathrm{ml}$ LPS group). OD, optical density.

Sigma-Aldrich (Sigma, St. Louis, MO, USA). TRIzol and electrophoresis reagents were purchased from Promega Co. (Promega, WI, USA). High sensitive CRP enzyme-linked immunosorbent assay (ELISA) kits were purchased from Daiichi Pure Chemicals Co., Ltd. (Daiichi Pure Chemicals, Japan). Atorvastatin was a gift from Beijing Honghui Medicine Co. (Honghui, China).
Cell culture. A549 cells were grown in DMEM supplemented with 5\% FBS, $100 \mu / \mathrm{ml}$ penicillin, $100 \mu / \mathrm{ml}$ streptomycin and $50 \mu \mathrm{g} / 1$ amphotericin B. Cultures were maintained at $37^{\circ} \mathrm{C}$ in a humidified atmosphere of air and $5 \% \mathrm{CO}_{2}$ Cells were sub-cultured into 6-well plates and maintained until subconfluence. The medium was then replaced by a serum-free culture medium for $24 \mathrm{~h}$ prior to the addition of LPS and/ or atorvastatin. The cells were then incubated with various concentrations of LPS for $24 \mathrm{~h}$, or $10 \mu \mathrm{g} / \mathrm{ml}$ LPS for various time periods. To investigate the effect of atorvastatin on the expression of CRP in vitro, the cells were incubated in the serum-free medium containing $10 \mu \mathrm{g} / \mathrm{ml}$ LPS in the absence (control group) or presence of an increased concentration of 10,15 and $20 \mu \mathrm{mol} / \mathrm{ml}$ atorvastatin for $24 \mathrm{~h}$.

RNA extraction and reverse transcriptase polymerase chain reaction. CRP messenger ribonucleic acid (mRNA) was measured by reverse transcriptase polymerase chain reaction (RT-PCR) as previously described (9). Briefly, total RNA from various experimental conditions was obtained using the TRIzol reagent method (Life Technologies, Carlsbad, CA, USA) and the concentration of RNA was determined by an absorbance at $260 \mathrm{~nm}$. For RT-PCR, $100 \mathrm{ng}$ of RNA from different experimental conditions was applied to the access RT-PCR System. The primers used for CRP were: forward: 5'-TTT TCT CGT ATG CCA CCA AG-3' and reverse: 5'-CTG GTG GGA GAC ATT GGA AA-3', which yielded products of $321 \mathrm{bp}$, and $\beta$-actin: forward: 5'-GTC ACC CAC ACT GTG CCC ATC-3' and reverse: 5'-ACA GAG TAC GCG CTC AGG AG-3', which yielded products of $542 \mathrm{bp}$. The PCR thermocycling conditions for the genes were: an initial denaturation for $4 \mathrm{~min}$ at $94^{\circ} \mathrm{C}, 35$ cycles with denaturation at $94^{\circ} \mathrm{C}$ for $1 \mathrm{~min}$, primer annealing at $55^{\circ} \mathrm{C}$ for $1 \mathrm{~min}$, primer extension at $72^{\circ} \mathrm{C}$ for $1 \mathrm{~min}$ and $20 \mathrm{sec}$, and a final extension step at $72^{\circ} \mathrm{C}$ for $10 \mathrm{~min}$. Each PCR product (5 $\mu \mathrm{l}$ ) was electrophoresed on $3-4 \mathrm{~mm}$ thick $1.5 \%$ agarose gels by electrophoresis and ethidium bromide stained bands were scanned by a Bio-Rad Gel Doc 2000 Imaging System (Bio-Rad Laboratories Ltd., UK). Optical density was analyzed using Quantity One 4.03 analysis software. The results for CRP mRNA levels were presented relative to the expression of $\beta$-actin.

CRP assay. After incubation, supernatants were collected to measure CRP. CRP was determined using ELISA kits as previously described (23). The high sensitivity human CRP ELISA kits are capable of detecting a minimal CRP concentration at $0.025 \mathrm{mg} / \mathrm{l}$. The process was strictly operated according to the manufacturer's instructions.

Statistical analysis. Statistical analysis was performed using SPSS 10.0 Software. Data are presented as mean \pm SD. The differences between the multiple treatment groups were analyzed by one-way ANOVA and the LSD test. For all tests, $\mathrm{p}<0.05$ was considered to be statistically significant.

\section{Results}

Various concentrations of LPS induced up-regulation of CRP mRNA and CRP in A549 cells. The human lung epithelial cell line A549 was selected as a model to investigate whether 
A

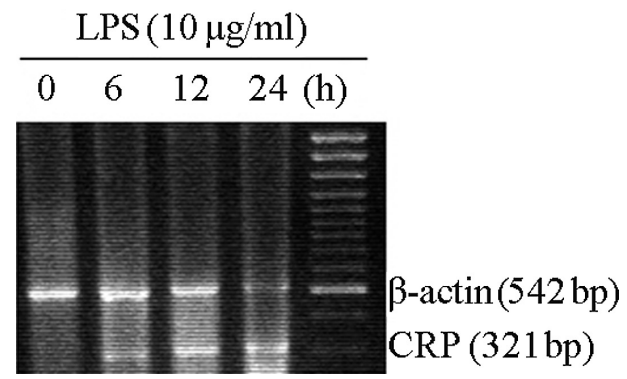

B

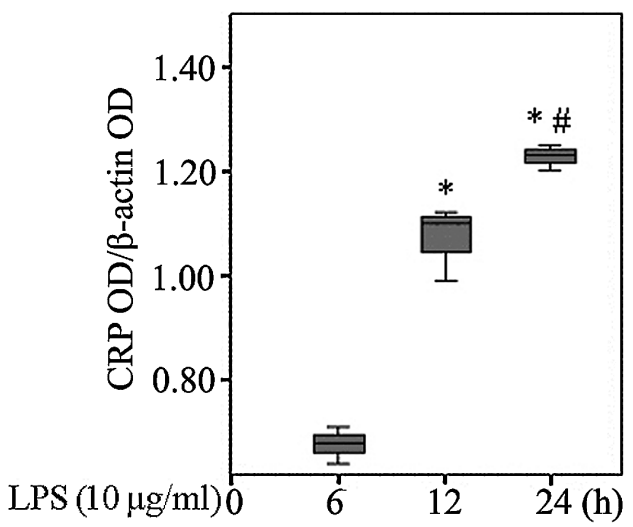

C

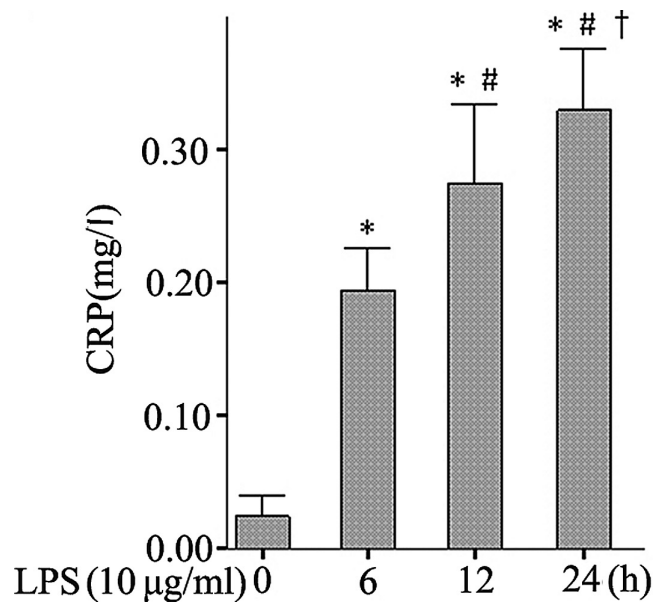

Figure 2. Time-dependent effects of lipopolysaccharide (LPS) on C-reactive protein (CRP) mRNA expression and CRP production. A549 cells were incubated with LPS $(10 \mu \mathrm{g} / \mathrm{ml})$ for various time periods. (A) A representative gel of CRP mRNA expression determined by RT-PCR. (B) Relative density of gel ( $\mathrm{p}=0.00$ vs. $6 \mathrm{~h}$ group; ${ }^{\sharp} \mathrm{p}=0.007$ vs. $12 \mathrm{~h}$ group). (C) CRP levels determined by ELISA at different time points ( $\mathrm{p}=0.00$ vs. control group; ${ }^{*} \mathrm{p}=0.00$ vs. $6 \mathrm{~h}$ group; ${ }^{\dagger} \mathrm{p}<0.05 \mathrm{vs} .12 \mathrm{~h}$ group). The data were representative of four independent experiments. OD, optical density.

LPS induces CRP production by human lung epithelial cells. A549 cells were incubated with various concentrations of LPS for $24 \mathrm{~h}$. RT-PCR analysis indicated that CRP mRNA expression in the presence of LPS was significantly higher than that in the absence of LPS in a dose-dependent manner $(\mathrm{p}<0.05)$ (Fig. 1A). No CRP mRNA expression was noted in the absence of LPS. A concentration of $5 \mu \mathrm{g} / \mathrm{ml}$ LPS was effective in the induction of CRP mRNA expression. LPS (10 and $15 \mu \mathrm{g} / \mathrm{ml})$ also increased CRP mRNA expression, but no significant difference was found between the two concentrations ( $p>0.05$ ).

Consistent with CRP mRNA expression, ELISA analysis revealed that CRP levels in the presence of LPS were
A

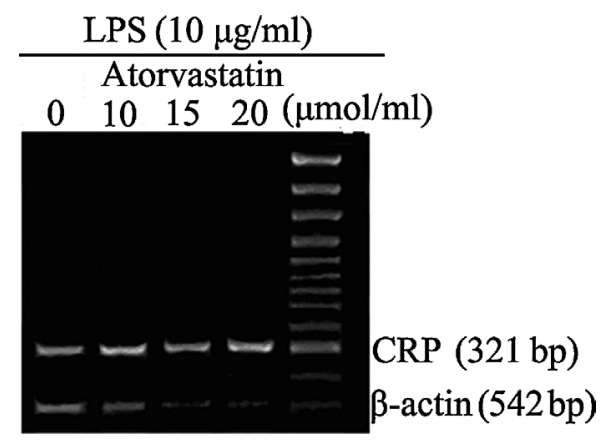

B

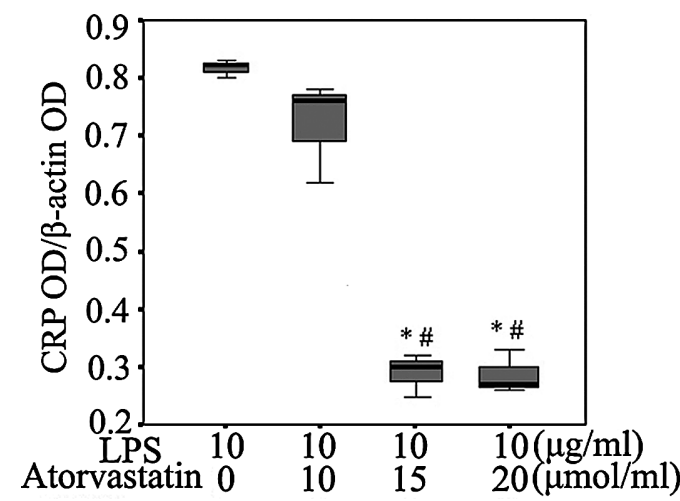

C

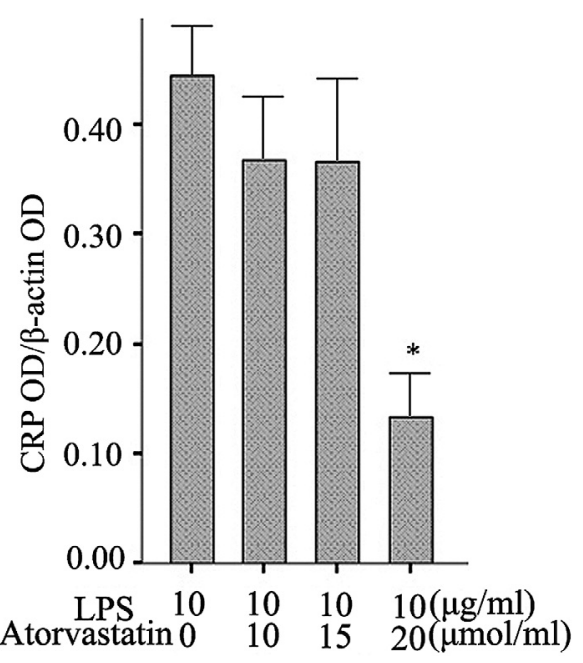

Figure 3. Atorvastatin reduces lipopolysaccharide (LPS)-induced C-reactive protein (CRP) mRNA expression and CRP production. A549 cells were treated with various concentrations of atorvastatin in the presence of LPS $(10 \mu \mathrm{g} / \mathrm{ml})$ for $24 \mathrm{~h}$. (A) A representative gel of CRP mRNA expression determined by RT-PCP. (B) Relative density of gel (" $\mathrm{p}=0.00$ vs. non-atorvastatin; ${ }^{\#} \mathrm{p}<0.05 \mathrm{vs} .10 \mu \mathrm{mol} / \mathrm{ml}$ atorvastatin group). (C) CRP levels determined by ELISA in the presence of LPS $(10 \mu \mathrm{g} / \mathrm{ml})$ with various concentrations of atorvastatin ( ${ }^{\sharp} \mathrm{p}<0.05$ vs. other groups). The data were representative of four independent experiments. OD, optical density.

significantly higher than those in the absence of LPS in a dose-dependent manner $(\mathrm{p}<0.05)$ (Fig. 1B).

Time-dependent effects of LPS on CRP mRNA expression and $C R P$ production. To determine the time-dependent effect of LPS, A549 cells were incubated with LPS $(10 \mu \mathrm{g} /$ $\mathrm{ml}$ ) for various time periods. CRP mRNA levels were increased in the presence of LPS at $10 \mu \mathrm{g} / \mathrm{ml}$ in a timedependent manner $(\mathrm{p}<0.05)$ (Fig. 2A). No CRP mRNA expression was found in the absence of LPS. The expression 
of CRP mRNA was increased by LPS as early as $6 \mathrm{~h}$, the earliest time point tested.

Similarly, CRP levels were increased in the presence of LPS at $10 \mu \mathrm{g} / \mathrm{ml}$ in a time-dependent manner $(\mathrm{p}<0.05)$ (Fig. 2B), significantly higher than those in the absence of LPS.

Atorvastatin decreases LPS-induced CRP mRNA levels and $C R P$ production in A549 cells. To determine whether atorvastatin affects LPS-induced CRP mRNA expression and CRP production, A549 cells were incubated with LPS in the presence or absence of various concentrations of atorvastatin for $24 \mathrm{~h}$. The expression of CRP mRNA induced by LPS was down-regulated by atorvastatin $(\mathrm{p}<0.05)$ (Fig. 3A). Consistent with this observation, LPS-induced CRP production was also inhibited by atorvastatin $(\mathrm{p}<0.05)$ (Fig. 3B). Atorvastatin inhibited LPS-induced CRP mRNA expression and CRP production in a dose-dependent manner.

\section{Discussion}

In the present study, we report for the first time that A549 cells are capable of LPS-induced CRP expression and that atorvastatin significantly decreased LPS-induced CRP expression in A549 cells. These results suggest that atorvastatin has direct anti-inflammatory effects on A549 cells.

CRP is generally thought to be produced only by hepatocytes (1) induced by interleukin-6 (IL-6). However, mounting evidence has revealed that other cells such as vascular smooth muscle cells (3), renal epithelial cells (4), adipocytes (5) and neuronal cells (6) also secrete CRP. More specifically, Gould and Weiser (7) reported that the human respiratory tract was able to produce CRP. Ramage et al reported that CRP was produced by A549 cells in response to cytokines, carbon particles and environmental air pollution particles $(8,9)$. Consistent with these results, our study revealed that LPS induced CRP secretion in A549 cells. In addition, we previously reported that A549 cells were capable of producing inflammatory biomediators, such as cyclooxygenase-2, IL-6 and prostaglandin E2 in response to LPS (24). Results of this study provided further support for the hypothesis that A549 cells were able to produce CRP and other inflammatory factors in response to inflammatory cytokines. Based on the pathway that hepatocytes synthesize and secrete CRP induced by IL- 6 (25), we postulate that IL-6 is involved in the LPS-induced CRP production of A549 cells, and that it may have a positive effect on CRP production in this process. In addition, the transcription factors STATs and NF- $\kappa \mathrm{B}$ are involved in $\mathrm{CRP}$ expression (26). Thus, we hypothesize that cytokines IL-6 are released rapidly by A549 cells induced by LPS, and that those factors then act on the cells to up-regulate the production of CRP by affecting the expression of the transcription factors STATs and NF- $\kappa$ B. Further studies are required in order to clarify the definite signaling mechanisms for the induction of CRP.

In addition to their established cholesterol-lowering properties, statins exert anti-inflammatory actions, including reducing serum CRP levels $(18,19)$. Previously, Arnaud et al reported that atorvastain decreased CRP production in human hepatocytes (25). In the present study, we report for the first time that atorvastatin is capable of reducing LPS-induced CRP production in A549 cells. These results provide new evidence of the direct anti-inflammatory effects of statins. The results also suggest that statins directly inhibit CRP expression in lung epithelial cells and hepatocytes that are capable of expressing CRP, thereby reducing serum CRP levels.

Numerous large observational studies have revealed a reduced incidence of pneumonia and improved pneumonia outcomes in patients receiving statins (27-30). These effects may be associated with reduced plasma CRP levels (27). More recently, results of a study showed that simvastatin not only reduced plasma CRP levels, but also decreased bronchoalveolar lavage fluid CRP levels of LPS-induced pulmonary inflammation in humans (31). This study confirmed that statins direct anti-inflammatory effects on lung epithelial cells. Thus, the results of this study are consistent with those of our study.

Inflammation in the lung itself as well as systemic inflammation have been shown to be involved in COPD (32). More specifically, mounting evidence suggests that serum CRP is a significant predictor of COPD outcome (33-37) and lung inflammation in COPD $(9,10)$. Previous studies indicated that statins ameliorated COPD survival $(20,21)$. Lee et al reported that pravastatin-treated COPD patients with a greater percentage decrease in CRP had a significant improvement in exercise time compared with those without CRP decrease (38). Based on these findings, we consider that statins are likely to improve COPD survival by reducing serum CRP levels. Our study as well as those of other authors revealed that human lung epithelial cells produced CRP (7-9). Epithelial and endothelial cell permeability may be increased during lung inflammation, allowing the movement of proteins across the lung-blood barrier (39). Therefore, CRP secreted by human lung epithelial cells may enter the systemic circulation and increase serum CRP levels in the presence or absence of a hepatic response. Thus, inhibiting CRP production in these cells may reduce serum CRP levels. We postulate that statins ameliorate COPD survival, partly through decreasing CRP expression in human lung epithelial cells.

The reasons that statins inhibited LPS-induced CRP expression in A549 cells are unclear. However, one specific mechanism may be involved. STAT3 is the transcription factor of CRP (40). Statins may inhibit STAT3 phosphorylation, thus inhibiting CRP gene expression (25). Further investigations are required to elucidate the mechanism of statin-inhibited CRP expression in A549 cells.

Although further studies are required, the present data reveal that A549 cells express CRP induced by LPS and that atorvastatin may reduce LPS-induced CRP expression in these cells. Our results indicate that statins may ameliorate the outcomes of COPD and pneumonia by regulating CRP production in human lung epithelial cells. These results may provide a further explanation of the beneficial effects of statins on lung inflammation in clinical trials.

\section{Acknowledgements}

This study was supported by grants from the Post-doctoral Foundation of Central South University. 


\section{References}

1. Gabay C and Kushner I: Acute-phase proteins and other systemic responses to inflammation. N Engl J Med 340: 448-454, 1999.

2. Claus DR, Osmand AP and Gewurz H: Radioimmunoassay of human C-reactive protein and levels in normal sera. J Lab Clin Med 87: 120-128, 1976.

3. Peng N, Liu JT, Gao DF, Lin R and Li R: Angiotensin II-induced C-reactive protein generation: inflammatory role of vascular smooth muscle cells in atherosclerosis. Atherosclerosis 193: 292-298, 2007

4. Jabs WJ, Logering BA, Gerke P, et al: The kidney as a second site of human C-reactive protein formation in vivo. Eur J Immunol 33 $152-161,2003$

5. Ouchi N, Kihara S, Funahashi T, et al: Reciprocal association of C-reactive protein with adiponectin in blood stream and adipose tissue. Circulation 107: 671-674, 2003.

6. Yasojima K, Schwab C, McGeer EG and McGeer PL: Human neurons generate $\mathrm{C}$-reactive protein and amyloid $\mathrm{P}$ : up-regulation in Alzheimer's disease. Brain Res 887: 80-89, 2000.

7. Gould JM and Weiser JN: Expression of C-reactive protein in the human respiratory tract. Infect Immun 69: 1747-1754, 2001

8. Ramage L and Guy K: Expression of C-reactive protein and heatshock protein-70 in the lung epithelial cell line A549, in response to PM10 exposure. Inhal Toxicol 16: 447-452, 2004.

9. Ramage L, Proudfoot L and Guy K: Expression of C-reactive protein in human lung epithelial cells and up-regulation by cytokines and carbon particles. Inhal Toxicol 16: 607-613, 2004.

10. Watterson TL, Hamilton B, Martin R and Coulombe RA Jr: Urban particulate matter causes ER stress and the unfolded protein response in human lung cells. Toxicol Sci 112: 111-122, 2009.

11. Wu SJ and Zhao SP: [Clinical observation and expression of C-reactive protein by LPS-induced A549 cells in patients with chronic obstructive pulmonary disease]. Zhong Nan Da Xue Xue Bao Yi Xue Ban (In Chinese) 30: 207-210, 2005.

12. Shepherd J, Cobbe SM, Ford I, et al: Prevention of coronary heart disease with pravastatin in men with hypercholesterolemia. West of Scotland Coronary Prevention Study Group. N Engl J Med 333: 1301-1307, 1995.

13. Hebert PR, Gaziano JM, Chan KS and Hennekens CH: Cholesterol lowering with statin drugs, risk of stroke, and total mortality. An overview of randomized trials. JAMA 278: 313-321, 1997.

14. Scandinavian Simvastatin Survival Study: Randomised trial of cholesterol lowering in 4444 patients with coronary heart disease: the Scandinavian simvastatin survival study $(4 \mathrm{~S})$. Lancet 344 1383-1389, 1994.

15. Vaughan CJ, Murphy MB and Buckley BM: Statins do more than just lower cholesterol. Lancet 348: 1079-1082, 1996.

16. Muhlestein JB, Anderson JL, Horne BD, et al: Early effects of statins in patients with coronary artery disease and high C-reactive protein. Am J Cardiol 94: 1107-1112, 2004.

17. Albert MA, Danielson E, Rifai N and Ridker PM: Effect of statin therapy on C-reactive protein levels: the pravastatin inflammation/CRP evaluation (PRINCE): a randomized trial and cohort study. JAMA 286: 64-70, 2001.

18. Nissen SE, Tuzcu EM, Schoenhagen P, et al: Statin therapy, LDL cholesterol, C-reactive protein, and coronary artery disease. N Engl J Med 352: 29-38, 2005.

19. Ridker PM, Cannon CP, Morrow D, et al: C-reactive protein levels and outcomes after statin therapy. N Engl J Med 352: 20-28, 2005.

20. Soyseth V, Brekke PH, Smith P and Omland T: Statin use is associated with reduced mortality in COPD. Eur Respir J 29: 279-283, 2007.

21. Mancini GB, Etminan M, Zhang B, Levesque LE, FitzGerald JM and Brophy JM: Reduction of morbidity and mortality by statins, angiotensin-converting enzyme inhibitors, and angiotensin receptor blockers in patients with chronic obstructive pulmonary disease. J Am Coll Cardiol 47: 2554-2560, 2006.
22. Van Eeden SF, Tan WC, Suwa T, et al: Cytokines involved in the systemic inflammatory response induced by exposure to particulate matter air pollutants (PM(10)). Am J Respir Crit Care Med 164: 826-830, 2001.

23. Suresh MV, Singh SK and Agrawal A: Interaction of calciumbound $\mathrm{C}$-reactive protein with fibronectin is controlled by $\mathrm{pH}$ : in vivo implications. J Biol Chem 279: 52552-52557, 2004.

24. Wu S, Duan S, Zhao S, Cai Y, Chen P and Fang X: Atorvastatin reduces lipopolysaccharide-induced expression of cyclooxygenase-2 in human pulmonary epithelial cells. Respir Res 6: 27, 2005.

25. Arnaud C, Burger F, Steffens S, et al: Statins reduce interleukin6-induced C-reactive protein in human hepatocytes: new evidence for direct antiinflammatory effects of statins. Arterioscler Thromb Vasc Biol 25: 1231-1236, 2005.

26. Li J, Li JJ, He JG, Nan JL, Guo YL and Xiong CM: Atorvastatin decreases C-reactive protein-induced inflammatory response in pulmonary artery smooth muscle cells by inhibiting nuclear factor- $\kappa$ B pathway. Cardiovasc Ther 28: 8-14, 2010.

27. Chalmers JD, Singanayagam A, Murray MP and Hill AT: Prior statin use is associated with improved outcomes in communityacquired pneumonia. Am J Med 121: 1002-1007.e1, 2008.

28. Van de Garde EM, Hak E, Souverein PC, Hoes AW, van den Bosch JM and Leufkens HG: Statin treatment and reduced risk of pneumonia in patients with diabetes. Thorax 61: 957-961, 2006.

29. Schlienger RG, Fedson DS, Jick SS, Jick H and Meier CR: Statins and the risk of pneumonia: a population-based, nested casecontrol study. Pharmacotherapy 27: 325-332, 2007.

30. Mortensen EM, Restrepo MI, Anzueto A and Pugh J: The effect of prior statin use on 30-day mortality for patients hospitalized with community-acquired pneumonia. Respir Res 6: 82, 2005.

31. Shyamsundar M, McKeown ST, O'Kane CM, et al: Simvastatin decreases lipopolysaccharide-induced pulmonary inflammation in healthy volunteers. Am J Respir Crit Care Med 179: 1107-1114, 2009.

32. Gan WQ, Man SF, Senthilselvan A and Sin DD: Association between chronic obstructive pulmonary disease and systemic inflammation: a systematic review and a meta-analysis. Thorax 59: 574-580, 2004.

33. Dahl M, Vestbo J, Lange P, Bojesen SE, Tybjaerg-Hansen A and Nordestgaard BG: C-reactive protein as a predictor of prognosis in chronic obstructive pulmonary disease. Am J Respir Crit Care Med 175: 250-255, 2007.

34. Man SF, Connett JE, Anthonisen NR, Wise RA, Tashkin DP and Sin DD: C-reactive protein and mortality in mild to moderate chronic obstructive pulmonary disease. Thorax 61: 849-853, 2006.

35. De Torres JP, Cordoba-Lanus E, Lopez-Aguilar C, et al: C-reactive protein levels and clinically important predictive outcomes in stable COPD patients. Eur Respir J 27: 902-907, 2006.

36. Broekhuizen R, Wouters EF, Creutzberg EC and Schols AM: Raised CRP levels mark metabolic and functional impairment in advanced COPD. Thorax 61: 17-22, 2006.

37. Hurst JR, Donaldson GC, Perera WR, et al: Use of plasma biomarkers at exacerbation of chronic obstructive pulmonary disease. Am J Respir Crit Care Med 174: 867-874, 2006.

38. Lee TM, Lin MS and Chang NC: Usefulness of C-reactive protein and interleukin- 6 as predictors of outcomes in patients with chronic obstructive pulmonary disease receiving pravastatin. Am J Cardiol 101: 530-535, 2008

39. Sedgwick JB, Menon I, Gern JE and Busse WW: Effects of inflammatory cytokines on the permeability of human lung microvascular endothelial cell monolayers and differential eosinophil transmigration. J Allergy Clin Immunol 110: 752-756, 2002.

40. Ochrietor JD, Harrison KA, Zahedi K and Mortensen RF: Role of STAT3 and C/EBP in cytokine-dependent expression of the mouse serum amyloid P-component (SAP) and C-reactive protein (CRP) genes. Cytokine 12: 888-899, 2000. 